\title{
PENDEKATAN THEORY OF CONSTRAINTS (TOC) PENJADWALAN FLOW SHOP PADA SISTEM PRODUKSI MAKE TO ORDER
}

\author{
Hera Rianti, Laila Nafisah, dan Eko Nursubiyantoro \\ Prodi Teknik Industri \\ Jurusan Teknik Industri, Fakultas Teknik Industri \\ Universitas Pembangunan Nasional "Veteran" Yogyakarta \\ Jl. Babarsari 2 Tambakbayan, Yogyakarta, 55281 \\ Telp. (0274) 485363 Fak : (0274) 486256 \\ email : lailanafisah71@gmail.com, eko_nsby072@upnyk.ac.id
}

\begin{abstract}
ABSTRAK
CV Putra Kilau Lampuan adalah erusahaan percetakan yang memproduksi buku, majalah, packaging, dan undangan. Sistem produksi yang diterapkan berbasis Make To Order (MTO) dengan pola aliran proses produksi bersifat flow shop. Perusahaan dihadapkan pada kendala banyaknya Work In Process (WIP) dengan kapasitas stasiun kerja yang terbatas, sehingga dapat menghambat aliran produksi dan waktu penyelesaian menjadi besar. Penelitian menggunakan metode penjadwalan drum buffer rope dengan konsep pendekatan Theory of Constraints (TOC) yang berfokus kepada pemanfaatan stasiun kerja bottleneck. Penjadwalan dimulai dari stasiun kerja bottleneck, kemudian baru dilakukan pada stasiun kerja non bottleneck. Penjadwalan pada stasiun kerja non bottleneck sebelum stasiun kerja bottleneck dilakukan secara backward, sedangkan stasiun kerja non bottleneck setelah stasiun kerja bottleneck dilakukan secara forward. Hasil dari penelitian ini yaitu diperoleh stasiun kerja penyusunan kertas isi (SK 10) terjadi bottleneck. Penjadwalan produksi berdasarkan stasiun kerja bottleneck menghasilkan urutan order dari stasiun kerja 1 sampai stasiun kerja 13 dengan makespan sebesar 26,215 hari. Makespan tersebut lebih singkat dibandingkan dengan makespan perusahaan yang besarnya 30,041 hari.
\end{abstract}

Kata kunci : flow shop, theory of constraints, drum buffer rope, makespan minimum

\section{PENDAHULUAN}

Industri manufaktur yang berkembang semakin pesat menuntut perusahaan untuk mampu berkompetisi didalam pasar persaingan. Perusahaan berusaha menyediakan yang terbaik bagi konsumen guna meningkatkan loyalitas, kredibilitas dan layanan perusahaan bagi konsumen. Salah satu hal yang digunakan untuk menunjukkan kredibilitas perusahaan adalah ketepatan waktu penyelesaian produk. Agar produk dapat selesai dengan waktu yang telah ditetapkan, perusahaan membutuhkan penjadwalan produksi yang tepat dalam pelaksanaan aktivitas proses produksinya.

CV Putra Kilau Lampuan merupakan sebuah perusahaan yang bergerak di bidang percetakan. Perusahaan ini berlokasi di Jalan Sedap Malam No.11, Gumpang, Kartasura, Sukoharjo, Jawa Tengah. Perusahaan ini memproduksi berbagai macam hasil cetakan kertas seperti buku, majalah, packaging, dan undangan. Sistem produksi yang diterapkan perusahaan berbasis Make To Order (MTO) yang berdasarkan jumlah permintaan konsumen dengan pola aliran proses produksi bersifat flow shop, dan prioritas pengerjaan pesanan berdasarkan metode First Come First Served (FCFS). Untuk mempertahankan kepercayaan konsumen, perusahaan berusaha menyelesaikan produk sesuai dengan waktu yang telah ditetapkan.

Selama ini perusahaan belum mampu memenuhi pesanan tepat pada waktunya. Pada sales order bulan Januari 2018, terdapat 9 pesanan dari 21 pesanan yang tidak sesuai jadwal yang disepakati (due date). Hal ini disebabkan oleh banyaknya Work In Process (WIP) atau barang setengah jadi menumpuk dengan kapasitas stasiun kerja yang terbatas. Pada pengamatan tanggal 14 Desember 2017, terjadi bottleneck pada proses produksi buku di stasiun kerja penyusunan kertas isi dengan kapasitas sebesar 736 lembar/jam lebih rendah dari stasiun kerja sebelumnya, yaitu stasiun kerja cetak kertas isi dengan kapasitas sebesar 5.000 lembar/jam. Kondisi seperti ini mengakibatkan di stasiun kerja tersebut terjadi penumpukan WIP yang menghambat aliran produksi dan waktu penyelesaian pesanan produksi menjadi besar. Masalah yang terus 
berlangsung tersebut dapat mengakibatkan resiko penurunan kredibilitas perusahaan di mata konsumen dan mengurangi daya kompetisi perusahaan dalam persaingan bisnis.

Peninjauan dalam penjadwalan di seluruh stasiun kerja dan mengidentifikasi stasiun kerja yang menjadi bottleneck dalam pembuatan penjadwalan berdasarkan beban kerja terbesar. Dari stasiun kerja bottleneck tersebut, ditentukan jadwal untuk memproduksi produk yang diinginkan. Penjadwalan produksi diharapkan mampu menangani bottleneck yang menghambat aliran produksi dan meminimumkan waktu penyelesaian order.

\section{LANDASAN TEORI}

\subsection{Sistem Produksi}

Sistem produksi merupakan kumpulan dari sub sistem yang saling berinteraksi dengan tujuan mentransformasi input produksi menjadi output produksi. Input produksi ini dapat berupa bahan baku, mesin, tenaga kerja, modal, dan informasi, sedangkan output produksi merupakan produk yang dihasilkan berikut hasil sampingnya seperti limbah, informasi, dan sebagainya (Ginting, 2007). Sistem produksi menurut tujuan operasi, dibedakan menjadi empat jenis, yaitu (Bedworth dan Bailey, 1987):

1) Engineering To Order (ETO), yaitu pemesan meminta produsen untuk membuat produk yang dimulai dari proses perancangannya (rekayasa).

2) Assembly To Order (ATO), yaitu produsen membuat desain standar, modul-modul opsinya standar dan merakit suatu kombinasi tertentu dari modul-modul tersebut. Modulmodul standar tersebut sesuai dengan pesanan konsumen dan bisa dirakit untuk berbagai tipe produk.

3) Make To Order (MTO), yaitu produsen menyelesaikan item akhirnya jika dan hanya jika menerima pesanan konsumen untuk item tersebut.

4) Make To Stock (MTS), yaitu produsen membuat item-item yang diselesaikan dan ditempatkan sebagai persediaan sebelum pesanan konsumen diterima. Item akhir tersebut baru akan dikirim dari sistem persediaannya setelah pesanan konsumen diterima.

Sistem produksi juga dibagi menurut aliran operasi dan variasi produk menjadi (Nasution dan Prasetyawan, 2007):
1) Flow Shop, yaitu proses konversi di mana unit-unit output secara berturut-turut melalui urutan operasi yang sama pada mesin-mesin khusus. Proses jenis ini biasanya digunakan untuk produk yang mempunyai desain dasar yang tetap sepanjang waktu yang lama dan ditujukan untuk pasar yang luas.

2) Continuous, proses ini merupakan bentuk ekstrim dari flow shop di mana terjadi aliran material yang konstan. Biasanya satu lintasan produksi pada proses kontiinyu hanya dialokasikan untuk satu produk saja.

3) Job Shop, yaitu merupakan bentuk proses konversi di mana unit-unit untuk pesanan yang berbeda pula dengan melalui pusatpusat kerja yang dikelompokkan berdasarkan fungsinya. Volume produksi tiap jenis sedikit, variasi produknya banyak, lama proses produksi tiap jenis produk agak panjang, tidak ada lintasan produksi khusus.

4) Batch, yaitu merupakan bentuk satu langkah kedepan dibandingkan job shop dalam hal standarisasi produk dengan memproduksi banyak variasi produk dan volume, lama proses produksi untuk tiap produk agak pendek, dan satu lintasan produksi dapat dipakai untuk beberapa tipe produk.

\subsection{Penjadwalan Produksi}

Menurut Baker (1974), penjadwalan adalah pengalokasian sumber daya yang terbatas untuk mengerjakan sejumlah pekerjaan. Tujuan penjadwalan, antara lain:

1) Meningkatkan penggunaan sumber daya atau mengurangi waktu tunggunya, sehingga total waktu proses dapat berkurang, dan produktivitas dapat meningkat.

2) Mengurangi persediaan barang setengah jadi atau mengurangi sejumlah pekerjaan yang menunggu dalam antrian ketika sumberdaya yang ada masih mengerjakan tugas yang lain.

3) Mengurangi beberapa kelambatan pada pekerjaan yang mempunyai batas waktu penyelesaian sehingga akan meminimasi penalti cost (biaya keterlambatan).

4) Membantu pengambilan keputusan mengenai perencanaan kapasitas pabrik dan jenis kapasitas yang dibutuhkan sehingga penambahan biaya yang mahal dapat dihindarkan.

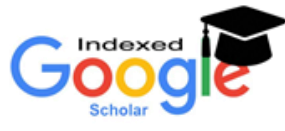




\subsection{Theory of Constraints (TOC)}

Fogarty dkk. (1991) menjelaskan bahwa TOC merupakan pengembangan dari Optimized Production Technology (OPT) yang menekankan pada optimasi pemanfaatan stasiun kendala. TOC menyatakan bahwa kendala harus diangkat, sehingga dapat diambil tindakan untuk mengurangi pengaruh hasilnya (throughput), persediaan, dan biaya operasi. Terdapat 5 langkah yang berurutan agar proses perbaikan lebih terfokus dan memberikan pengaruh positif yang lebih baik bagi sistem sebelumnya (Narasimhan dkk, 1995), yaitu:

1) Identifikasi kendala dalam sistem (identify the system's constraint).

2) Tentukan bagaimana cara untuk melakukan eksploitasi kendala sistem (describe how to exploit the system's constraints)

3) Subordinasi segala hal untuk mendukung keputusan (subordinate everything else to the above decision)

4) Tingkatkan kemampuan kendala untk memecahkan masalah (elevate the system's constraint)

5) Jika pada langkah sebelumnya, kendala lama dipecahkan namun muncul kendala baru, kembali ke langkah 1 .

\subsection{Drum Buffer Rope}

Dalam konsep TOC dikenal dengan istilah "drum-buffer-rope", yang merupakan teknik umum yang digunakan untuk mengelola sumber-sumber daya guna memaksimumkan performansi dari sistem (Gaspersz, 2001). Drum adalah ritme produksi yang ditetapkan untuk mengatasi kendala sistem. Buffer atau penyangga digunakan untuk menjaga bottleneck dari fluktuasi stasiun-stasiun kerja sebelumnya. Dalam sistem produksi terdapat dua macam buffer, yaitu:

\section{1) Time buffer}

Waktu yang dijadikan penyangga dengan tujuan untuk melindungi laju produksi (throughput) sistem dari gangguan yang selalu terjadi dalam sistem produksi.

\section{2) Stock Buffer}

Produk akhir maupun produk antara yang dijadikan penyangga dengan tujuan untuk memperbaiki sistem produksi dalam hal menanggapi permintaan.

\subsection{Algoritma Zijm}

Algoritma Zijm ditemukan oleh seorang professor di Belanda yang bernama WHK Zijm. Zijm (1994) menjelaskan bahwa algoritma Zijm memberikan logika pendeteksian mesin bottleneck yang terjadi pada suatu sistem berdasarkan parameter-parameter yang telah ditentukan. Selain mendeteksi terjadinya bottleneck, algoritma ini juga memberikan salah satu parameter yang dibutuhkan untuk untuk meningkatkan kinerja mesin bottleneck yaitu menghasilkan time buffers. Model matematis yang digunakan adalah sebagai berikut (Kushana dkk,2014):

1) Langkah 1: Menghitung laju permintaan pada setiap operasi di seluruh stasiun kerja untuk setiap order.

$$
\begin{aligned}
& D^{(h)}=\frac{1}{M L T}=\frac{1}{\left(d^{(h)}-r j\right) m} \\
& \text { dengan: } \\
& \text { MLT: Manufacturing Lead Time } \\
& d^{(h)} \quad: \text { Due date job } \mathrm{h} \\
& r_{j} \quad \text { : saat siap di mesin } \mathrm{j} \\
& m \text { : jumlah mesin }
\end{aligned}
$$

2) Langkah 2: Menghitung laju kedatangan pada setiap operasi di seluruh stasiun kerja untuk setiap order.

$$
\lambda^{(h)}=\frac{D^{(h)}}{Q^{(h)}} \delta^{(h)}
$$

dengan:

$\lambda^{(h)}$ : laju kedatangan job $\mathrm{h}$

$D^{(h)}$ : laju permintaan job $\mathrm{h}$

$Q^{(h)}:$ ukuran lot produksi job $\mathrm{h}=1$

$\delta_{j k}^{(h)}\left\{\begin{array}{c}1, j i k a \text { job } h \text {, proses } k \text {, stasiun kerja } j \\ - \\ 0, \text { untuk yang lainnya }\end{array}\right.$

3) Langkah 3: Menghitung waktu proses pada setiap operasi di seluruh stasiun kerja untuk setiap order.

$$
P_{j k}^{(h)}=Z_{j k}^{(h)}+\left(Q_{j k}^{(h)} x a_{j k}^{(h)}\right)
$$

dengan:

$P_{j k}^{(h)}$ : waktu proses job $h$, proses ke- $k$, di stasiun kerja $j$

$Z_{j k}^{(h)}$ : waktu set up job $h$, proses ke- $k$, di stasiun kerja $j$

$Q_{j k}^{(h)}$ : ukuran lot produksi job $h$, proses ke- $k$, di stasiun kerja $j$

$a_{j k}^{(h)}$ : waktu proses job $h$, proses ke- $k$, di stasiun kerja $j$

4) Langkah 4: Menghitung beban kerja pada setiap operasi di seluruh stasiun kerja untuk 
setiap order dan penjumlahan beban kerja untuk setiap stasiun kerjanya.

$\rho_{j}=\sum_{h . k} \lambda_{j k}^{(h)} x P_{j k}^{(h)}$

dengan:

$\rho_{j}$ : rata-rata beban kerja di mesin $j$

5) Langkah 5: Menghitung waktu tunggu pada setiap operasi di seluruh stasiun kerja untuk setiap order dan penjumlahan beban kerja untuk setiap stasiun kerjanya.

$E_{j}=\frac{\sum_{h . k} \lambda_{j k}^{(h)} x\left(P_{j k}^{(h)}\right)^{2}}{2\left(1-\rho_{j}\right)}$

Dengan:

$E(j)=$ ekspektasi waktu tunggu di stasiun kerja $j$

6) Langkah 6: Menghitung perkiraan lead time pada setiap operasi di seluruh stasiun kerja untuk setiap order.

$E\left(T_{j k}^{(h)}\right)=E_{j}+P_{j k}^{(h)}$

7) Langkah 7: menghitung Etc dan Ltc

Berfungsi untuk menentukan Etc (saat paling awal setiap order bisa mulai dikerjakan di stasiun kendala) dan Ltc (saat paling akhir setiap order bisa mulai dikerjakan di stasiun kendala) setiap pesanan. Etc dan Ltc merupakan salah satu kriteria untuk pemilihan pesanan yang akan didistribusikan, penentuan solusi inisial, dan pemeriksaaan kelayakan setiap pesanan yang telah dijadwalkan.

$$
\begin{aligned}
& E T C^{(h)}=r^{(h)}+\sum_{h=1}^{m}\left(t_{h}+w_{h}\right) \ldots \ldots \ldots \\
& L T C^{(h)}=d^{(h)}-\sum_{h=1}^{m}\left(t_{h}+w_{h}\right)-t h
\end{aligned}
$$

dengan:

$$
\begin{array}{ll}
E\left(T^{(h)}\right) & \text { : ekspektasi rata-rata lead time job } h \\
m & : \text { jumlah mesin setelah bottleneck } \\
t_{h} & : \text { waktu proses job } h \\
w_{h} & : \text { ekspektasi waktu menunggu job } h \\
E T C^{(h)} & : \text { Earliest Time Completion job } h \\
L_{T} C^{(h)} & : \text { Latest Time Completion job } h
\end{array}
$$

\section{METODOLOGI PENELITIAN}

Obyek dari peneltian ini adalah salah satu perusahaan percetakan, CV Putra Kilau Lampuan yang berlokasi di Jalan Sedap Malam
No.11, Surakarta. Kerangka pemecahan masalah dan pengolahan data disusun sebagai berikut:

1) Mengidentifikasi stasiun kerja bottleneck dengan algoritma zijm.

a. Menghitung laju permintaan pada setiap operasi di seluruh stasiun kerja untuk setiap order.

b. Menghitung laju kedatangan pada setiap operasi di seluruh stasiun kerja untuk setiap order.

c. Menghitung waktu proses pada setiap operasi di seluruh stasiun kerja untuk setiap order.

d. Menghitung beban kerja pada setiap operasi di seluruh stasiun kerja untuk setiap order dan penjumlahan beban kerja untuk setiap stasiun kerjanya

e. Menghitung ekspektasi waktu tunggu pada setiap operasi di seluruh stasiun kerja untuk setiap order dan penjumlahan beban kerja untuk setiap stasiun.

f. Menghitung ekspektasi lead time pada setiap operasi di seluruh stasiun kerja untuk setiap order.

g. Menentukan Etc (saat paling awal setiap order bisa mulai dikerjakan di stasiun kerja bottleneck dan Ltc (saat paling akhir setiap order bisa mulai dikerjakan di stasiun kerja bottleneck) setiap pesanan.

2). Melakukan penjadwalan produksi di stasiun kerja bottleneck dan stasiun kerja non bottleneck sebelum stasiun kerja bottleneck menggunakan backward scheduling. Untuk stasiun kerja non bottleneck setelah stasiun kerja bottleneck menggunakan forward scheduling.

\section{HASIL DAN PEMBAHASAN \\ 4.1 Identifikasi stasiun kerja bottleneck}

Identifikasi stasiun kerja bottleneck

\begin{tabular}{|c|c|c|c|c|c|c|c|c|c|c|c|c|c|}
\hline \multirow{2}{*}{ No Order } & \multicolumn{13}{|c|}{ Laju Permintaan/jam } \\
\hline & SK 1 & SK 2 & SK 3 & SK 4 & SK 5 & SK 6 & SK 7 & SK 8 & SK 9 & SK 10 & SK 11 & SK 12 & SK 13 \\
\hline 1 & 0,006 & 0,006 & 0,000 & 0,000 & 0,000 & 0,000 & 0,006 & 0,000 & 0,006 & 0,006 & 0,006 & 0,006 & 0,006 \\
\hline 2 & 0,006 & 0,006 & 0,000 & 0,000 & 0,006 & 0,000 & 0,006 & 0,000 & 0,006 & 0,006 & 0,006 & 0,006 & 0,006 \\
\hline 3 & 0,007 & 0,007 & 0,000 & 0,000 & 0,007 & 0,000 & 0,007 & 0,000 & 0,007 & 0,007 & 0,007 & 0,007 & 0,007 \\
\hline 4 & 0,007 & 0,007 & 0,000 & 0,000 & 0,007 & 0,007 & 0,007 & 0,000 & 0,007 & 0,007 & 0,007 & 0,007 & 0,007 \\
\hline 5 & 0,006 & 0,006 & 0,000 & 0,000 & 0,000 & 0,000 & 0,006 & 0,000 & 0,006 & 0,006 & 0,006 & 0,006 & 0,006 \\
\hline 6 & 0,005 & 0,000 & 0,005 & 0,005 & 0,005 & 0,005 & 0,005 & 0,000 & 0,005 & 0,005 & 0,005 & 0,005 & \\
\hline 7 & 0,007 & 0,000 & 0,007 & 0,007 & 0,007 & 0,000 & 0,007 & 0,007 & 0,000 & 0,000 & 0,000 & Irog,be0'c & \\
\hline
\end{tabular}
menggunakan algoritma zijm. Langkahlangkahnya adalah sebagai berikut:

1) Menghitung laju permintaan

Laju permintaan dihitung menggunakan Langkah 1, hasil perhitungan laju permintaan dapat dilihat pada Tabel 1 berikut ini:

Tabel 1 Hasil perhitungan laju permintaan 


\begin{tabular}{|c|c|c|c|c|c|c|c|c|c|c|c|c|c|}
\hline \multirow{2}{*}{ No Order } & \multicolumn{13}{|c|}{ Laju Permintaan/jam } \\
\hline & SK 1 & SK 2 & SK 3 & SK 4 & SK 5 & SK 6 & SK 7 & SK 8 & SK 9 & SK 10 & SK 11 & SK 12 & SK 13 \\
\hline 8 & 0,006 & 0,006 & 0,000 & 0,000 & 0,006 & 0,000 & 0,006 & 0,000 & 0,006 & 0,006 & 0,006 & 0,006 & 0,006 \\
\hline 9 & 0,006 & 0,006 & 0,000 & 0,000 & 0,006 & 0,006 & 0,006 & 0,000 & 0,006 & 0,006 & 0,006 & 0,006 & 0,006 \\
\hline 10 & 0,006 & 0,006 & 0,000 & 0,000 & 0,006 & 0,000 & 0,006 & 0,000 & 0,006 & 0,006 & 0,006 & 0,006 & 0,006 \\
\hline 11 & 0,006 & 0,000 & 0,006 & 0,006 & 0,006 & 0,000 & 0,006 & 0,006 & 0,000 & 0,000 & 0,000 & 0,000 & 0,006 \\
\hline 12 & 0,005 & 0,000 & 0,005 & 0,005 & 0,005 & 0,005 & 0,005 & 0,000 & 0,005 & 0,005 & 0,005 & 0,005 & 0,005 \\
\hline 13 & 0,006 & 0,000 & 0,006 & 0,006 & 0,006 & 0,006 & 0,006 & 0,006 & 0,000 & 0,000 & 0,000 & 0,000 & 0,006 \\
\hline 14 & 0,006 & 0,006 & 0,000 & 0,000 & 0,006 & 0,006 & 0,006 & 0,006 & 0,000 & 0,000 & 0,000 & 0,000 & 0,006 \\
\hline 15 & 0,006 & 0,000 & 0,006 & 0,006 & 0,006 & 0,006 & 0,006 & 0,000 & 0,006 & 0,006 & 0,006 & 0,006 & 0,006 \\
\hline 16 & 0,005 & 0,005 & 0,000 & 0,000 & 0,005 & 0,005 & 0,005 & 0,000 & 0,005 & 0,005 & 0,005 & 0,005 & 0,005 \\
\hline 17 & 0,007 & 0,007 & 0,000 & 0,000 & 0,007 & 0,000 & 0,007 & 0,000 & 0,007 & 0,007 & 0,007 & 0,007 & 0,007 \\
\hline 18 & 0,006 & 0,000 & 0,006 & 0,006 & 0,006 & 0,006 & 0,006 & 0,000 & 0,006 & 0,006 & 0,006 & 0,006 & 0,006 \\
\hline 19 & 0,006 & 0,006 & 0,000 & 0,000 & 0,006 & 0,000 & 0,006 & 0,000 & 0,006 & 0,006 & 0,006 & 0,006 & 0,006 \\
\hline 20 & 0,006 & 0,006 & 0,000 & 0,000 & 0,000 & 0,006 & 0,006 & 0,006 & 0,000 & 0,000 & 0,000 & 0,000 & 0,006 \\
\hline 21 & 0,006 & 0,006 & 0,000 & 0,000 & 0,006 & 0,006 & 0,006 & 0,006 & 0,000 & 0,000 & 0,000 & 0,000 & 0,006 \\
\hline 22 & 0,006 & 0,000 & 0,006 & 0,006 & 0,006 & 0,006 & 0,006 & 0,000 & 0,006 & 0,006 & 0,006 & 0,006 & 0,006 \\
\hline 23 & 0,006 & 0,006 & 0,000 & 0,000 & 0,006 & 0,006 & 0,006 & 0,000 & 0,006 & 0,006 & 0,006 & 0,006 & 0,006 \\
\hline 24 & 0,006 & 0,006 & 0,000 & 0,000 & 0,006 & 0,000 & 0,006 & 0,000 & 0,006 & 0,006 & 0,006 & 0,006 & 0,006 \\
\hline
\end{tabular}

2) Menghitung laju kedatangan

Laju kedatangan untuk setiap order menggunakan Langkah 2 dan hasil perhitungan laju kedatangan dapat dilihat pada Tabel 2.

Tabel 2 Hasil perhitungan laju kedatangan

\begin{tabular}{|c|c|c|c|c|c|c|c|c|c|c|c|c|c|}
\hline \multirow{2}{*}{ No Order } & \multicolumn{13}{|c|}{ Laju kedatangan/jam } \\
\hline & SK 1 & SK 2 & SK 3 & SK 4 & SK 5 & SK 6 & SK 7 & SK 8 & SK 9 & SK 10 & SK 11 & SK 12 & SK13 \\
\hline 1 & 0,006 & 0,006 & 0,000 & 0,000 & 0,000 & 0,000 & 0,006 & 0,000 & 0,006 & 0,006 & 0,006 & 0,006 & 0,006 \\
\hline 2 & 0,006 & 0,006 & 0,000 & 0,000 & 0,006 & 0,000 & 0,006 & 0,000 & 0,006 & 0,006 & 0,006 & 0,006 & 0,006 \\
\hline 3 & 0,007 & 0,007 & 0,000 & 0,000 & 0,007 & 0,000 & 0,007 & 0,000 & 0,007 & 0,007 & 0,007 & 0,007 & 0,007 \\
\hline 4 & 0,007 & 0,007 & 0,000 & 0,000 & 0,007 & 0,007 & 0,007 & 0,000 & 0,007 & 0,007 & 0,007 & 0,007 & 0,007 \\
\hline 5 & 0,006 & 0,006 & 0,000 & 0,000 & 0,000 & 0,000 & 0,006 & 0,000 & 0,006 & 0,006 & 0,006 & 0,006 & 0,006 \\
\hline 6 & 0,005 & 0,000 & 0,005 & 0,005 & 0,005 & 0,005 & 0,005 & 0,000 & 0,005 & 0,005 & 0,005 & 0,005 & 0,005 \\
\hline 7 & 0,007 & 0,000 & 0,007 & 0,007 & 0,007 & 0,000 & 0,007 & 0,007 & 0,000 & 0,000 & 0,000 & 0,000 & 0,007 \\
\hline 8 & 0,006 & 0,006 & 0,000 & 0,000 & 0,006 & 0,000 & 0,006 & 0,000 & 0,006 & 0,006 & 0,006 & 0,006 & 0,006 \\
\hline 9 & 0,006 & 0,006 & 0,000 & 0,000 & 0,006 & 0,006 & 0,006 & 0,000 & 0,006 & 0,006 & 0,006 & 0,006 & 0,006 \\
\hline 10 & 0,006 & 0,006 & 0,000 & 0,000 & 0,006 & 0,000 & 0,006 & 0,000 & 0,006 & 0,006 & 0,006 & 0,006 & 0,006 \\
\hline 11 & 0,006 & 0,000 & 0,006 & 0,006 & 0,006 & 0,000 & 0,006 & 0,006 & 0,000 & 0,000 & 0,000 & 0,000 & 0,006 \\
\hline 12 & 0,005 & 0,000 & 0,005 & 0,005 & 0,005 & 0,005 & 0,005 & 0,000 & 0,005 & 0,005 & 0,005 & 0,005 & 0,005 \\
\hline 13 & 0,006 & 0,000 & 0,006 & 0,006 & 0,006 & 0,006 & 0,006 & 0,006 & 0,000 & 0,000 & 0,000 & 0,000 & 0,006 \\
\hline 14 & 0,006 & 0,006 & 0,000 & 0,000 & 0,006 & 0,006 & 0,006 & 0,006 & 0,000 & 0,000 & 0,000 & 0,000 & 0,006 \\
\hline 15 & 0,006 & 0,000 & 0,006 & 0,006 & 0,006 & 0,006 & 0,006 & 0,000 & 0,006 & 0,006 & 0,006 & 0,006 & 0,006 \\
\hline 16 & 0,005 & 0,005 & 0,000 & 0,000 & 0,005 & 0,005 & 0,005 & 0,000 & 0,005 & 0,005 & 0,005 & 0,005 & 0,005 \\
\hline 17 & 0,007 & 0,007 & 0,000 & 0,000 & 0,007 & 0,000 & 0,007 & 0,000 & 0,007 & 0,007 & 0,007 & 0,007 & 0,007 \\
\hline 18 & 0,006 & 0,000 & 0,006 & 0,006 & 0,006 & 0,006 & 0,006 & 0,000 & 0,006 & 0,006 & 0,006 & 0,006 & 0,006 \\
\hline 19 & 0,006 & 0,006 & 0,000 & 0,000 & 0,006 & 0,000 & 0,006 & 0,000 & 0,006 & 0,006 & 0,006 & 0,006 & 0,006 \\
\hline 20 & 0,006 & 0,006 & 0,000 & 0,000 & 0,000 & 0,006 & 0,006 & 0,006 & 0,000 & 0,000 & 0,000 & 0,000 & 0,006 \\
\hline 21 & 0,006 & 0,006 & 0,000 & 0,000 & 0,006 & 0,006 & 0,006 & 0,006 & 0,000 & 0,000 & 0,000 & 0,000 & 0,006 \\
\hline 22 & 0,006 & 0,000 & 0,006 & 0,006 & 0,006 & 0,006 & 0,006 & 0,000 & 0,006 & 0,006 & 0,006 & 0,006 & 0,006 \\
\hline 23 & 0,006 & 0,006 & 0,000 & 0,000 & 0,006 & 0,006 & 0,006 & 0,000 & 0,006 & 0,006 & 0,006 & 0,006 & 0,006 \\
\hline 24 & 0,006 & 0,006 & 0,000 & 0,000 & 0,006 & 0,000 & 0,006 & 0,000 & 0,006 & 0,006 & 0,006 & 0,006 & 0,006 \\
\hline
\end{tabular}

3). Menghitung waktu proses pengerjaan order

Laju kedatangan untuk setiap order menggunakan Langkah 2 dan hasil waktu proses pengerjaan order dapat dilihat pada Tabel 3.

Tabel 3 Hasil perhitungan waktu proses pengerjaan order

\begin{tabular}{|c|c|c|c|c|c|c|c|c|c|c|c|c|c|}
\hline \multirow{2}{*}{ No Order } & \multicolumn{13}{|c|}{ Waktu Proses (jam) } \\
\hline & SK 1 & SK 2 & SK 3 & SK 4 & SK 5 & SK 6 & SK 7 & SK 8 & SK 9 & SK 10 & SK 11 & SK 12 & SK 13 \\
\hline 1 & 0,956 & 0,728 & 0,000 & 0,000 & 0,000 & 0,000 & 0,483 & 0,000 & 0,894 & 0,928 & 1,178 & 0,789 & 0,317 \\
\hline 2 & 0,769 & 0,300 & 0,000 & 0,000 & 0,937 & 0,000 & 0,198 & 0,000 & 1,142 & 1,012 & 1,127 & 0,631 & 0,249 \\
\hline 3 & 0,983 & 0,884 & 0,000 & 0,000 & 5,183 & 0,000 & 0,556 & 0,000 & 5,248 & 6,866 & 1,972 & 3,155 & 1,351 \\
\hline 4 & 1,110 & 1,023 & 0,000 & 0,000 & 6,300 & 1,780 & 0,673 & 0,000 & 10,273 & 14,679 & 2,929 & 6,032 & 2,608 \\
\hline 5 & 0,844 & 0,548 & 0,000 & 0,000 & 0,000 & 0,000 & 0,360 & 0,000 & 5,347 & 7,091 & 1,959 & 3,126 & 1,337 \\
\hline 6 & 1,065 & 0,000 & 0,768 & 1,040 & 5,117 & 1,640 & 0,617 & 0,000 & 4,344 & 5,543 & 1,795 & 2,635 & 1,126 \\
\hline 7 & 1,035 & 0,000 & 1,055 & 1,110 & 7,667 & 0,000 & 1,137 & 2,217 & 0,000 & 0,000 & 0,000 & 0,000 & 1,138 \\
\hline
\end{tabular}




\begin{tabular}{|c|c|c|c|c|c|c|c|c|c|c|c|c|c|}
\hline \multirow{2}{*}{ No Order } & \multicolumn{13}{|c|}{ Waktu Proses (jam) } \\
\hline & SK 1 & SK 2 & SK 3 & SK 4 & SK 5 & SK 6 & SK 7 & SK 8 & SK 9 & SK 10 & SK 11 & SK 12 & SK 13 \\
\hline 8 & 0,897 & 0,903 & 0,000 & 0,000 & 7,500 & 0,000 & 0,496 & 0,000 & 4,500 & 1,808 & 1,164 & 0,743 & 0,297 \\
\hline 9 & 1,415 & 1,602 & 0,000 & 0,000 & 9,333 & 2,807 & 1,083 & 0,000 & 11,034 & 15,193 & 3,131 & 6,644 & 2,872 \\
\hline 10 & 1,022 & 0,809 & 0,000 & 0,000 & 3,521 & 0,000 & 0,550 & 0,000 & 3,854 & 4,849 & 1,703 & 2,330 & 0,991 \\
\hline 11 & 1,060 & 0,000 & 0,991 & 1,129 & 4,533 & 0,000 & 0,658 & 1,953 & 0,000 & 0,000 & 0,000 & 0,000 & 0,910 \\
\hline 12 & 0,961 & 0,000 & 1,089 & 1,061 & 14,167 & 1,622 & 0,611 & 0,000 & 8,300 & 11,272 & 2,578 & 4,978 & 2,144 \\
\hline 13 & 1,100 & 0,000 & 1,015 & 1,010 & 6,767 & 1,510 & 0,562 & 2,157 & 0,000 & 0,000 & 0,000 & 0,000 & 1,883 \\
\hline 14 & 0,870 & 0,717 & 0,000 & 0,000 & 3,667 & 1,033 & 0,377 & 0,843 & 0,000 & 0,000 & 0,000 & 0,000 & 0,887 \\
\hline 15 & 0,876 & 0,000 & 0,781 & 0,839 & 6,992 & 1,175 & 0,434 & 0,000 & 8,972 & 12,361 & 2,668 & 5,251 & 2,264 \\
\hline 16 & 0,853 & 0,669 & 0,000 & 0,000 & 5,417 & 1,019 & 0,372 & 0,000 & 5,469 & 7,253 & 1,989 & 3,222 & 1,378 \\
\hline 17 & 1,309 & 1,744 & 0,000 & 0,000 & 12,817 & 0,000 & 1,093 & 0,000 & 12,142 & 16,730 & 3,365 & 7,354 & 3,182 \\
\hline 18 & 1,078 & 0,000 & 1,156 & 1,206 & 7,500 & 1,906 & 0,728 & 0,000 & 6,061 & 7,972 & 2,117 & 3,711 & 1,594 \\
\hline 19 & 0,843 & 0,590 & 0,000 & 0,000 & 3,100 & 0,000 & 0,353 & 0,000 & 5,496 & 7,319 & 1,984 & 3,206 & 1,372 \\
\hline 20 & 1,171 & 0,796 & 0,000 & 0,000 & 0,000 & 1,008 & 0,371 & 0,767 & 0,000 & 0,000 & 0,000 & 0,000 & 0,867 \\
\hline 21 & 1,058 & 0,846 & 0,000 & 0,000 & 10,750 & 1,221 & 0,458 & 1,938 & 0,000 & 0,000 & 0,000 & 0,000 & 0,554 \\
\hline 22 & 0,939 & 0,000 & 0,958 & 0,986 & 6,400 & 2,403 & 0,544 & 0,000 & 6,960 & 9,339 & 2,308 & 4,174 & 1,793 \\
\hline 23 & 0,826 & 0,546 & 0,000 & 0,000 & 2,138 & 0,893 & 0,322 & 0,000 & 2,114 & 2,354 & 1,340 & 1,273 & 0,531 \\
\hline 24 & 0,899 & 0,735 & 0,000 & 0,000 & 4,833 & 0,000 & 0,444 & 0,000 & 8,405 & 11,557 & 2,549 & 4,901 & 2,112 \\
\hline 19 & 0,843 & 0,590 & 0,000 & 0,000 & 3,100 & 0,000 & 0,353 & 0,000 & 5,496 & 7,319 & 1,984 & 3,206 & 1,372 \\
\hline
\end{tabular}

4). Menghitung rata-rata beban kerja

Rata-rata beban kerja menggunakan Langkah 3 dan hasil perhitungan rata-rata beban kerja pada stasiun kerja dapat dilihat pada Tabel 4.

Tabel 4 Hasil perhitungan rata-rata beban kerja

\begin{tabular}{|c|c|c|c|c|c|c|c|c|c|c|c|c|c|}
\hline \multirow{2}{*}{ No Order } & \multicolumn{13}{|c|}{ Beban Kerja } \\
\hline & SK 1 & SK 2 & SK 3 & SK 4 & SK 5 & SK 6 & SK 7 & SK 8 & SK 9 & SK 10 & SK 11 & SK 12 & SK 13 \\
\hline 1 & 0,006 & 0,005 & 0,000 & 0,000 & 0,000 & 0,000 & 0,003 & 0,000 & 0,006 & 0,006 & 0,008 & 0,005 & 0,002 \\
\hline 2 & 0,005 & 0,002 & 0,000 & 0,000 & 0,006 & 0,000 & 0,001 & 0,000 & 0,007 & 0,006 & 0,007 & 0,004 & 0,002 \\
\hline 3 & 0,007 & 0,006 & 0,000 & 0,000 & 0,035 & 0,000 & 0,004 & 0,000 & 0,036 & 0,047 & 0,013 & 0,021 & 0,009 \\
\hline 4 & 0,008 & 0,007 & 0,000 & 0,000 & 0,043 & 0,012 & 0,005 & 0,000 & 0,070 & 0,100 & 0,020 & 0,041 & 0,018 \\
\hline 5 & 0,005 & 0,003 & 0,000 & 0,000 & 0,000 & 0,000 & 0,002 & 0,000 & 0,032 & 0,042 & 0,012 & 0,019 & 0,008 \\
\hline 6 & 0,006 & 0,000 & 0,004 & 0,006 & 0,027 & 0,009 & 0,003 & 0,000 & 0,023 & 0,029 & 0,009 & 0,014 & 0,006 \\
\hline 7 & 0,007 & 0,000 & 0,007 & 0,008 & 0,052 & 0,000 & 0,008 & 0,015 & 0,000 & 0,000 & 0,000 & 0,000 & 0,008 \\
\hline 8 & 0,005 & 0,005 & 0,000 & 0,000 & 0,045 & 0,000 & 0,003 & 0,000 & 0,027 & 0,011 & 0,007 & 0,004 & 0,002 \\
\hline 9 & 0,008 & 0,010 & 0,000 & 0,000 & 0,056 & 0,017 & 0,006 & 0,000 & 0,066 & 0,090 & 0,019 & 0,040 & 0,017 \\
\hline 10 & 0,006 & 0,005 & 0,000 & 0,000 & 0,022 & 0,000 & 0,003 & 0,000 & 0,024 & 0,030 & 0,011 & 0,014 & 0,006 \\
\hline 11 & 0,007 & 0,000 & 0,006 & 0,007 & 0,028 & 0,000 & 0,004 & 0,012 & 0,000 & 0,000 & 0,000 & 0,000 & 0,006 \\
\hline 12 & 0,005 & 0,000 & 0,006 & 0,006 & 0,078 & 0,009 & 0,003 & 0,000 & 0,046 & 0,062 & 0,014 & 0,027 & 0,012 \\
\hline 13 & 0,007 & 0,000 & 0,007 & 0,007 & 0,044 & 0,010 & 0,004 & 0,014 & 0,000 & 0,000 & 0,000 & 0,000 & 0,012 \\
\hline 14 & 0,005 & 0,004 & 0,000 & 0,000 & 0,023 & 0,006 & 0,002 & 0,005 & 0,000 & 0,000 & 0,000 & 0,000 & 0,006 \\
\hline 15 & 0,005 & 0,000 & 0,005 & 0,005 & 0,042 & 0,007 & 0,003 & 0,000 & 0,053 & 0,074 & 0,016 & 0,031 & 0,013 \\
\hline 16 & 0,005 & 0,004 & 0,000 & 0,000 & 0,030 & 0,006 & 0,002 & 0,000 & 0,030 & 0,040 & 0,011 & 0,018 & 0,008 \\
\hline 17 & 0,009 & 0,012 & 0,000 & 0,000 & 0,087 & 0,000 & 0,007 & 0,000 & 0,083 & 0,114 & 0,023 & 0,050 & 0,022 \\
\hline 18 & 0,007 & 0,000 & 0,007 & 0,007 & 0,047 & 0,012 & 0,005 & 0,000 & 0,038 & 0,050 & 0,013 & 0,023 & 0,010 \\
\hline 19 & 0,005 & 0,004 & 0,000 & 0,000 & 0,020 & 0,000 & 0,002 & 0,000 & 0,036 & 0,048 & 0,013 & 0,021 & 0,009 \\
\hline 20 & 0,008 & 0,005 & 0,000 & 0,000 & 0,000 & 0,007 & 0,002 & 0,005 & 0,000 & 0,000 & 0,000 & 0,000 & 0,006 \\
\hline 21 & 0,007 & 0,005 & 0,000 & 0,000 & 0,070 & 0,008 & 0,003 & 0,013 & 0,000 & 0,000 & 0,000 & 0,000 & 0,004 \\
\hline 22 & 0,006 & 0,000 & 0,006 & 0,006 & 0,040 & 0,015 & 0,003 & 0,000 & 0,043 & 0,058 & 0,014 & 0,026 & 0,011 \\
\hline 23 & 0,005 & 0,003 & 0,000 & 0,000 & 0,013 & 0,005 & 0,002 & 0,000 & 0,013 & 0,014 & 0,008 & 0,008 & 0,003 \\
\hline 24 & 0,006 & 0,005 & 0,000 & 0,000 & 0,030 & 0,000 & 0,003 & 0,000 & 0,052 & 0,072 & 0,016 & 0,030 & 0,013 \\
\hline Jmlh & 0,149 & 0,085 & 0,048 & 0,051 & 0,836 & 0,122 & 0,084 & 0,064 & 0,683 & 0,892 & 0,233 & 0,397 & 0,211 \\
\hline
\end{tabular}

5) Menghitung waktu tunggu

Perhitungan waktu tunggu setiap order di setiap stasiun kerja menggunakan Langkah 5 dan hasil perhitungan waktu tunggu setiap order dapat dilihat pada Tabel 5.

Tabel 5 Hasil perhitungan waktu tunggu

\begin{tabular}{|c|c|c|c|c|c|c|c|c|c|c|c|c|c|}
\hline \multirow{2}{*}{$\begin{array}{c}\text { No } \\
\text { Order }\end{array}$} & SK1 & SK2 & SK3 & SK4 & SK5 & SK6 & SK7 & SK 8 & SK 9 & SK 10 & SK 11 & SK 12 & SK 13 \\
\hline 1 & 0,006 & 0,003 & 0,000 & 0,000 & 0,000 & 0,000 & 0,002 & 0,000 & 0,005 & 0,006 & 0,009 & 0,004 & 0,001 \\
\hline 2 & 0,004 & 0,001 & 0,000 & 0,000 & 0,005 & 0,000 & 0,000 & 0,000 & 0,008 & 0,006 & 0,008 & 0,002 & 0,000 \\
\hline 3 & 0,007 & 0,005 & 0,000 & 0,000 & 0,183 & 0,000 & 0,002 & 0,000 & 0,187 & 0,321 & 0,026 & 0,068 & 0,012 \\
\hline 4 & 0,008 & 0,007 & 0,000 & 0,000 & 0,270 & 0,022 & 0,003 & 0,000 & 0,718 & 1,466 & 0,058 & 0,248 & 0,046 \\
\hline 5 & 0,004 & 0,002 & 0,000 & 0,000 & 0,000 & 0,000 & 0,001 & 0,000 & 0,170 & 0,299 & 0,023 & 0,058 & 0,011 \\
\hline 6 & 0,006 & 0,000 & 0,003 & 0,006 & 0,139 & 0,014 & 0,002 & 0,000 & 0,100 & 0,163 & 0,017 & 0,037 & 0.007 \\
\hline 7 & 0,007 & 0,000 & 0,008 & 0,008 & 0,400 & 0,000 & 0,009 & 0,033 & 0,000 & 0,000 & 0,000 & Indonded & 的 \\
\hline
\end{tabular}




\begin{tabular}{|c|c|c|c|c|c|c|c|c|c|c|c|c|c|}
\hline \multirow{2}{*}{$\begin{array}{c}\text { No } \\
\text { Order }\end{array}$} & \multicolumn{13}{|c|}{ Waktu tunggu (jam) } \\
\hline & SK1 & SK2 & SK3 & SK4 & SK5 & SK6 & SK7 & SK 8 & SK 9 & SK 10 & SK 11 & SK 12 & SK 13 \\
\hline 8 & 0,005 & 0,005 & 0,000 & 0,000 & 0,335 & 0,000 & 0,001 & 0,000 & 0,121 & 0,019 & 0,008 & 0,003 & 0,001 \\
\hline 9 & 0,012 & 0,015 & 0,000 & 0,000 & 0,519 & 0,047 & 0,007 & 0,000 & 0,725 & 1,374 & 0,058 & 0,263 & 0,049 \\
\hline 10 & 0,006 & 0,004 & 0,000 & 0,000 & 0,077 & 0,000 & 0,002 & 0,000 & 0,092 & 0,146 & 0,018 & 0,034 & 0,006 \\
\hline 11 & 0,007 & 0,000 & 0,006 & 0,008 & 0,128 & 0,000 & 0,003 & 0,024 & 0,000 & 0,000 & 0,000 & 0,000 & 0,005 \\
\hline 12 & 0,005 & 0,000 & 0,007 & 0,006 & 1,103 & 0,014 & 0,002 & 0,000 & 0,379 & 0,698 & 0,037 & 0,136 & 0,025 \\
\hline 13 & 0,008 & 0,000 & 0,007 & 0,007 & 0,297 & 0,015 & 0,002 & 0,030 & 0,000 & 0,000 & 0,000 & 0,000 & 0,023 \\
\hline 14 & 0,005 & 0,003 & 0,000 & 0,000 & 0,084 & 0,007 & 0,001 & 0,004 & 0,000 & 0,000 & 0,000 & 0,000 & 0,005 \\
\hline 15 & 0,005 & 0,000 & 0,004 & 0,004 & 0,291 & 0,008 & 0,001 & 0,000 & 0,479 & 0,910 & 0,042 & 0,164 & 0,031 \\
\hline 16 & 0,004 & 0,002 & 0,000 & 0,000 & 0,161 & 0,006 & 0,001 & 0,000 & 0,164 & 0,289 & 0,022 & 0,057 & 0,010 \\
\hline 17 & 0,012 & 0,021 & 0,000 & 0,000 & 1,117 & 0,000 & 0,008 & 0,000 & 1,003 & 1,904 & 0,077 & 0,368 & 0,069 \\
\hline 18 & 0,007 & 0,000 & 0,008 & 0,009 & 0,349 & 0,023 & 0,003 & 0,000 & 0,228 & 0,395 & 0,028 & 0,086 & 0,016 \\
\hline 19 & 0,005 & 0,002 & 0,000 & 0,000 & 0,062 & 0,000 & 0,001 & 0,000 & 0,196 & 0,348 & 0,026 & 0,067 & 0,012 \\
\hline 20 & 0,009 & 0,004 & 0,000 & 0,000 & 0,000 & 0,007 & 0,001 & 0,004 & 0,000 & 0,000 & 0,000 & 0,000 & 0,005 \\
\hline 21 & 0,007 & 0,005 & 0,000 & 0,000 & 0,750 & 0,010 & 0,001 & 0,024 & 0,000 & 0,000 & 0,000 & 0,000 & 0,002 \\
\hline 22 & 0,005 & 0,000 & 0,006 & 0,006 & 0,254 & 0,036 & 0,002 & 0,000 & 0,301 & 0,542 & 0,033 & 0,108 & 0,020 \\
\hline 23 & 0,004 & 0,002 & 0,000 & 0,000 & 0,027 & 0,005 & 0,001 & 0,000 & 0,027 & 0,033 & 0,011 & 0,010 & 0,002 \\
\hline 24 & 0,005 & 0,003 & 0,000 & 0,000 & 0,145 & 0,000 & 0,001 & 0,000 & 0,439 & 0,830 & 0,040 & 0,149 & 0,028 \\
\hline Jmlh & 0,153 & 0,085 & 0,048 & 0,054 & 6,697 & 0,212 & 0,057 & 0,120 & 5,342 & 9,747 & 0,541 & 1,861 & 0,394 \\
\hline w.tunggu & 0,090 & 0,046 & 0,025 & 0,029 & 20,357 & 0,121 & 0,031 & 0,064 & 8,418 & 45,021 & 0,353 & 1,542 & 0,249 \\
\hline
\end{tabular}

5) Setelah melihat hasil perhitungan dari beban kerja pada Tabel 4 dan perhitungan waktu tunggu pada Tabel 5 di atas, stasiun yang mempunyai beban kerja terbesar dan ekspektasi waktu menunggu setiap order di stasiun paling lama adalah Stasiun Kerja Penyusunan Kertas Isi (SK 10). Oleh sebab itu, Stasiun Kerja Penyusunan Kertas Isi ditetapkan sebagai stasiun kerja bottleneck.

\subsection{Perhitungan lead time}

Perhitungan perkiraan lead time diselesaikan menggunakan Langkah 6 dan hasil seluruh perhitungan perkiraan lead time dapat dilihat pada Tabel 6 .

Tabel 6 Perhitungan lead time

\begin{tabular}{|c|c|c|c|c|c|c|c|c|c|c|c|c|c|}
\hline \multirow{3}{*}{ No Order } & \multicolumn{13}{|c|}{ Perkiraan lead time (jam) } \\
\hline & \multicolumn{9}{|c|}{ Sebelum stasiun kerja bottleneck } & \multirow{2}{*}{$\begin{array}{c}\text { St. bottleneck } \\
\text { SK } 10 \\
\end{array}$} & \multicolumn{3}{|c|}{ Setelah stasiun bottleneck } \\
\hline & SK1 & SK2 & SK3 & SK 4 & SK 5 & SK 6 & SK 7 & SK 8 & SK 9 & & SK 11 & SK 12 & SK 13 \\
\hline 1 & 1,045 & 0,774 & 0,025 & 0,029 & 20,357 & 0,121 & 0,514 & 0,064 & 9,312 & 45,949 & 1,531 & 2,331 & 0,566 \\
\hline 2 & 0,859 & 0,347 & 0,025 & 0,029 & 21,294 & 0,121 & 0,229 & 0,064 & 9,560 & 46,033 & 1,480 & 2,173 & 0,499 \\
\hline 3 & 1,073 & 0,930 & 0,025 & 0,029 & 25,540 & 0,121 & 0,586 & 0,064 & 13,666 & 51,887 & 2,325 & 4,697 & 1,601 \\
\hline 4 & 1,200 & 1,070 & 0,025 & 0,029 & 26,657 & 1,901 & 0,704 & 0,064 & 18,691 & 59,700 & 3,282 & 7,574 & 2,857 \\
\hline 5 & 0,934 & 0,594 & 0,025 & 0,029 & 20,357 & 0,121 & 0,391 & 0,064 & 13,765 & 52,112 & 2,312 & 4,668 & 1,587 \\
\hline 6 & 1,155 & 0,046 & 0,793 & 1,069 & 25,474 & 1,761 & 0,648 & 0,064 & 12,761 & 50,564 & 2,148 & 4,177 & 1,375 \\
\hline 7 & 1,125 & 0,046 & 1,080 & 1,139 & 28,024 & 0,121 & 1,168 & 2,281 & 8,418 & 45,021 & 0,353 & 1,542 & 1,388 \\
\hline 8 & 0,986 & 0,950 & 0,025 & 0,029 & 27,857 & 0,121 & 0,526 & 0,064 & 12,918 & 46,829 & 1,517 & 2,286 & 0,546 \\
\hline 9 & 1,504 & 1,648 & 0,025 & 0,029 & 29,690 & 2,928 & 1,114 & 0,064 & 19,452 & 60,214 & 3,484 & 8,186 & 3,121 \\
\hline 10 & 1,111 & 0,855 & 0,025 & 0,029 & 23,878 & 0,121 & 0,581 & 0,064 & 12,272 & 49,871 & 2,056 & 3,872 & 1,240 \\
\hline 11 & 1,150 & 0,046 & 1,016 & 1,157 & 24,890 & 0,121 & 0,688 & 2,018 & 8,418 & 45,021 & 0,353 & 1,542 & 1,159 \\
\hline 12 & 1,051 & 0,046 & 1,114 & 1,090 & 34,524 & 1,743 & 0,642 & 0,064 & 16,718 & 56,293 & 2,931 & 6,520 & 2,394 \\
\hline 13 & 1,190 & 0,046 & 1,040 & 1,039 & 27,124 & 1,631 & 0,593 & 2,221 & 8,418 & 45,021 & 0,353 & 1,542 & 2,133 \\
\hline 14 & 0,960 & 0,763 & 0,025 & 0,029 & 24,024 & 1,154 & 0,408 & 0,907 & 8,418 & 45,021 & 0,353 & 1,542 & 1,136 \\
\hline 15 & 0,966 & 0,046 & 0,806 & 0,868 & 27,349 & 1,296 & 0,465 & 0,064 & 17,389 & 57,382 & 3,021 & 6,794 & 2,514 \\
\hline 16 & 0,943 & 0,716 & 0,025 & 0,029 & 25,774 & 1,140 & 0,403 & 0,064 & 13,887 & 52,274 & 2,342 & 4,764 & 1,627 \\
\hline 17 & 1,399 & 1,791 & 0,025 & 0,029 & 33,174 & 0,121 & 1,123 & 0,064 & 20,559 & 61,751 & 3,718 & 8,896 & 3,431 \\
\hline 18 & 1,168 & 0,046 & 1,181 & 1,234 & 27,857 & 2,026 & 0,759 & 0,064 & 14,479 & 52,993 & 2,470 & 5,253 & 1,844 \\
\hline 19 & 0,933 & 0,636 & 0,025 & 0,029 & 23,457 & 0,121 & 0,384 & 0,064 & 13,913 & 52,340 & 2,337 & 4,748 & 1,622 \\
\hline 20 & 1,261 & 0,842 & 0,025 & 0,029 & 20,357 & 1,129 & 0,402 & 0,831 & 8,418 & 45,021 & 0,353 & 1,542 & 1,116 \\
\hline 21 & 1,148 & 0,892 & 0,025 & 0,029 & 31,107 & 1,342 & 0,489 & 2,002 & 8,418 & 45,021 & 0,353 & 1,542 & 0,804 \\
\hline 22 & 1,029 & 0,046 & 0,983 & 1,015 & 26,757 & 2,524 & 0,575 & 0,064 & 15,378 & 54,360 & 2,661 & 5,716 & 2,042 \\
\hline 23 & 0,916 & 0,592 & 0,025 & 0,029 & 22,495 & 1,013 & 0,353 & 0,064 & 10,532 & 47,376 & 1,693 & 2,815 & 0,780 \\
\hline 24 & 0,989 & 0,782 & 0,025 & 0,029 & 25,190 & 0,121 & 0,474 & 0,064 & 16,823 & 56,578 & 2,902 & 6,443 & 2,361 \\
\hline
\end{tabular}

\subsection{Perhitungan Etc dan Ltc}

Penentuan Etc dan Ltc dapat diselesaikan menggunakan Langkah 7. Hasil seluruh perhitungan Hasil perhitungan selengkapnya dapat dilihat pada Tabel 7. 
Tabel 7 Perhitungan Etc dan Ltc

\begin{tabular}{|c|c|c|c|c|}
\hline Order & $\begin{array}{c}\text { Kode } \\
\text { Produk }\end{array}$ & Etc & Ltc & Status \\
\hline 1 & A1 & 172,241 & 281,644 & Layak \\
\hline 2 & A2 & 172,527 & 288,836 & Layak \\
\hline 3 & A3 & 182,034 & 264,511 & Layak \\
\hline 4 & A4 & 190,340 & 251,607 & Layak \\
\hline 5 & A5 & 162,280 & 271,343 & Layak \\
\hline 6 & A6 & 176,770 & 301,756 & Layak \\
\hline 7 & B1 & 176,400 & 269,717 & Layak \\
\hline 8 & A7 & 176,476 & 287,843 & Layak \\
\hline 9 & A8 & 182,454 & 257,016 & Layak \\
\hline 10 & A9 & 164,936 & 267,983 & Layak \\
\hline 11 & B2 & 172,503 & 283,945 & Layak \\
\hline 12 & A10 & 189,991 & 284,883 & Layak \\
\hline 13 & B3 & 176,300 & 275,972 & Layak \\
\hline 14 & B4 & 162,687 & 276,969 & Layak \\
\hline 15 & A11 & 175,249 & 262,310 & Layak \\
\hline 16 & A12 & 168,980 & 285,014 & Layak \\
\hline 17 & A13 & 177,284 & 226,224 & Layak \\
\hline 18 & A14 & 167,813 & 255,461 & Layak \\
\hline 19 & A15 & 158,562 & 249,974 & Layak \\
\hline 20 & C1 & 159,292 & 269,989 & Layak \\
\hline 21 & B5 & 171,451 & 270,301 & Layak \\
\hline 22 & A16 & 174,371 & 260,241 & Layak \\
\hline 23 & A17 & 162,019 & 279,357 & Layak \\
\hline 24 & A18 & 170,497 & 256,736 & Layak \\
\hline
\end{tabular}

Berdasarkan pemeriksaan Etc dan Ltc pada Tabel 7 menunjukkan seluruh order layak untuk dijadwalkan.

\subsection{Penjadwalan stasiun kerja}

Penjadwalan berdasarkan pada stasiun kerja bottleneck menggunakan aturan due date. Due date setiap order pada SK 10 menunjukkan urutan order. Starting time due date terbesar menjadi completion time order sebelumnya di SK 10 menggunakan aturan backward. Completion time due date menjadi starting time order setelah SK 10 menggunakan aturan forward. Urutan order dari hasil penjadwalan adalah 17,11, 21, 20, 19, 18, 24, 14, 22, 10, 4, 7, $3,23,15,9,13,5,1,8,2,16,12$, dan 6 .

\footnotetext{
Analisis Hasil

Penjadwalan produksi menggunakan pendekatan Theory of Constraints (TOC) mengkonsentrasikan pengendalian di stasiun kerja bottleneck. Stasiun kerja bottleneck digunakan sebagai penggerak dalam penjadwalan produksi. Metode penjadwalan yang menggunakan prinsip-prinsip TOC adalah Drum Buffer Rope (DBR). Algoritma Zijm merupakan algoritma yang dapat mengidentifikasi stasiun kerja bottleneck yang digunakan sebagai titik pengendalian penjadwalan. Di antara 13 stasiun kerja yang ada di CV Putra Kilau Lampuan, stasiun kerja yang menjadi stasiun kerja bottleneck adalah stasiun kerja 10 (Penyusunan kertas isi). SK 10
}

menjadi stasiun kerja bottleneck karena memiliki ekspektasi waktu tunggu terbesar dengan nilai 45,021 jam, sebanding dengan ratarata beban kerja dengan nilai 0,892 , dan waktu prosesnya. Penyebab stasiun kerja 10 dijadikan stasiun kerja bottleneck adalah kemungkinan adanya keterlambatan dalam menjadwalkan pesanan ke stasiun kerja dan urutan penjadwalan yang salah. Metode forward scheduling yang digunakan perusahaan tidak menjamin pengerjaan pesanan yang dapat meminimasi flowtime pada stasiun kerja bottleneck sehingga terjadi keterlambatan. Penyebab lainnya diakibatkan karena kapasitas stasiun kerja. Pada proses produksi, terdapat bottleneck pada Stasiun Kerja Penyusunan Kertas Isi. Hal ini terjadi karena pada stasiun kerja sebelumnya (Stasiun Kerja Cetak Kertas Isi) memiliki kapasitas lebih besar, yaitu produksi 5.000 lembar/jam yang kemudian ditumpuk di Stasiun Kerja Penyusunan Kertas Isi yang hanya memiliki kapasitas sebesar 736 lembar/jam. Stasiun kerja bottleneck ini menjadi titik kontrol atau patokan penjadwalan, sehingga diutamakan produktivitas kerjanya dapat maksimal agar mempelancar jadwal produksi.

Algortima zijm juga dapat dilakukan untuk perhitungan buffer Buffer yang digunakan adalah time buffer. Buffer ini digunakan untuk menjaga utilitas stasiun kerja dapat bekerja dengan maksimal. Besarnya buffer yang diberikan adalah 45,021 jam. Selisih waktu antara stasiun kerja bottleneck dan stasiun kerja non bottleneck sebelumnya diharapkan dapat menjaga keseimbangan penjadwalan produksi. Seluruh stasiun kerja non bottleneck sebelum bottleneck dapat terlambat, namun keterlambatannya tidak boleh melebihi dari besarnya buffer time yang diberikan di stasiun kerja tersebut.

Penjadwalkan pesanan di stasiun kerja bottleneck (SK 10) menggunakan aturan backward scheduling, yaitu menjadwalkan selambat mungkin untuk memenuhi due date yang telah ditentukan. Penjadwalan dengan aturan backward scheduling akan meminimasi WIP di lantai produksi karena pesanan masuk ke lantai produksi disesuaikan dengan kapasitas produksi pada stasiun kerja bottleneck sehingga pesanan datang sesaat sebelum dikerjakan di stasiun kerja bottleneck.

Penjadwalan stasiun kerja non bottleneck berpatokan pada hasil dari stasiun kerja 10 yang merupakan stasiun kerja bottleneck. Dalam melakukan penjadwalan di 
bottleneck, dipisahkan antara stasiun kerja sebelum dan sesudah stasiun kerja bottleneck. Penjadwalan sebelum stasiun kerja bottleneck menggunakan aturan backward scheduling (penjadwalan mundur), yaitu menjadwalkan selambat mungkin, namun tetap tiba tepat waktu di stasiun kerja bottleneck. Starting time suatu order di stasiun kerja bottleneck merupakan completion time untuk pesanan tepat sebelum stasiun kerja bottleneck. Hasil penjadwalan menggunakan backward scheduling menghasilkan waktu mulai yaitu pada jam ke 136,213 masih di dalam jadwal feasible (layak). Hal ini dapat dilihat dari waktu mulai yang tidak kurang dari pre order pesanan terakhir.

Penjadwalan stasiun kerja setelah stasiun kerja bottleneck menggunakan aturan penjadwalan maju (forward scheduling), yaitu menjadwalkan sesegera mungkin dalam penyelesaian suatu pesanan. Completion time suatu order di stasiun kerja bottleneck merupakan starting time order tersebut pada stasiun kerja tepat setelah stasiun kerja bottleneck. Penjadwalan maju menghasilkan waktu selesai pengerjaan pesanan, yaitu jam ke 319,719. Terjadi keterlambatan dalam penyelesaian order sesuai dengan due date terbesar. Urutan order dari hasil penjadwalan adalah $17,11,21,20,19,18,24,14$, $22,10,4,7,3,23,15,9,13,5,1,8,2,16,12$, dan 6. Urutan Penjadwalan Produksi Perusahaan menghasilkan makespan sebesar 30,0416 hari dan Gantt Chart Penjadwalan Produksi Usulan menghasilkan makespan sebesar 26,215 hari.

\section{KESIMPULAN}

Perencanaan produksi yang tepat untuk memperoleh waktu penyelesaian order minimum adalah dengan menjadwalkan setiap stasiun kerja berdasarkan stasiun kerja bottleneck. Berdasarkan pengolahan data dan analisis hasil, bottleneck terjadi di Stasiun kerja Penyusunan Kertas Isi (SK 10). Penjadwalan produksi berdasarkan stasiun kerja bottleneck menghasilkan urutan order dari stasiun kerja 1 sampai dengan stasiun kerja 13 dengan makespan sebesar 26,215 hari. Makespan tersebut lebih singkat dibandingkan dengan makespan perusahaan yang besarnya 30,041 hari.

\section{DAFTAR PUSTAKA}

Baker, K.R., 1974, Introduction to Sequencing and Scheduling, John Wiley and Sons, Inc., New York.
Bedworth, D.D, dan Bailey, J.E., 1987, Integrated Production and Control System: Management, Analysis, and Design, John Wiley and Sons, Inc., New York.

Fogarty, D.W., Blackstone, J.H., dan Hoffmann, T.R., 1991, Production and Inventory Management, 2nd Edition, South-Western Publising Co., Cincinnati, Ohio.

Gasperzs, V., 2001, Production Planning and Inventory Control Berdasarkan Pendekatan Sistem Terintegrasi MRP II dan JIT Menuju manufacturing 21, PT Gramedia Pustaka Utama, Jakarta.

Ginting, R., 2007, Sistem Produksi, Graha Ilmu, Yogyakarta.

Ginting, R., 2009, Penjadwalan Mesin, Graha Ilmu, Yogyakarta.

Hansen, D.R., dan Mowen, M. M., 2000, Akuntansi Manajemen Jilid 2, Erlangga, Jakarta.

Iriadi, D. W., 2005, Penjadwalan Sistem Produksi Job Shop Menggunakan Theory of Constraints dengan Backward dan Forward Schedulling, Tugas Akhir, Universitas Islam Indonesia, Yogyakarta.

Kushana, D.N.S., Zaini, E., Saleh, A., 2014, Rancangan sistem penjadwalan buku fiksi dengan pendekatan theory of constraints di PT. Mizan Grafika Sarana, Jurnal Teknik Industri Itenas, Institut Teknologi Nasional, Bandung.

Narasimhan, S.L., McLeavy, D.W., dan Billington, P.J., 1995, Production and Planning Inventory Control, Prentice Hall, Inc., New Jersey.

Nasution, A.H dan Prasetyawan, Y., 2008, Perencanaan dan Pengendalian Produksi, Graha Ilmu, Yogyakarta.

Tersine, R.J., 1994, Principles of Inventory and Materials Management, 4th Edition,Prentice Hall, Inc., New Jersey.

Umble, M.M., dan Srikanth, M.L., 1996, Synchronous Manufacturing, The Spectrum Publishing Company, Inc., Boston.

Zijm, W.H.M., dan Buitenhek, R., 1996, Capacity planning and lead time management, International Journal of Economic, University of Twente, Netherland. 